\title{
Strategic Planning of Physical Education and Sports in Iranian Schools Using QSPM Matrix
}

\author{
${ }^{1}$ Mohammad Rahim ${ }^{(D)}{ }^{*}{ }^{1}$ Mehrzad Hamidi ${ }^{(D)}{ }^{3}$ Nazanin Rasekh \\ ${ }^{1}$ Ministry of Education, Physical Education Department, Tehran, Iran. ${ }^{2}$ Department of Sport Management, \\ Faculty of Sports Science, University of Tehran, Tehran, Iran. ${ }^{3}$ Department of Sport Management, Sport \\ Sciences Research Institute of Iran (SSRI), Tehran, Iran.
}

Submitted 12 February 2021; Accepted in final form 24 April 2021.

\begin{abstract}
Background. Considering the existence of FRDE (Fundamental Reform Document of Education) as a national guideline, there is a need to design strategies for physical education and sports in schools, so that due to the limited resources, reaching the desired targets and plans outlined in the FRDE become possible. Objectives. The purpose of this study is to strategically plan the physical education and sports of Iranian students using the QSPM matrix with a mixed (qualitative-quantitative) method. Methods. The sample of the quantitative section was physical education staff members of the general departments and headquarters (deputy, director, and expert) which was a total of 120 people. The main search tools were as follows: 1- The questionnaire, In the qualitative part, the participants included thirteen professors and knowledgeable experts in the field of education who were interviewed to determine the main components of the questionnaire. 2- IFE, EFE, and SWOT matrices were used to determine the strategic position and strategy development and a quantitative strategic planning matrix (QSPM) was used to prioritize the strategies. Results. The results showed that the strategic position of physical education and sports in Iranian schools is in an offensive position and has six strengths, six weaknesses, six opportunities, and six threats. Analyses determined Four SO strategies, two WO strategies, two ST strategies and one WT strategy, and a total of nine strategies. Conclusion. It seems that based on the prioritization of strategies, the promotion of students' motor literacy, as well as a healthy and active lifestyle as the main targets in physical education and sports in schools, should be considered by policymakers in this field.
\end{abstract}

\section{KEYWORDS: Strategic Planning, Student Sports, Physical Education in Schools, SWOT, QSPM.}

\section{INTRODUCTION}

The genuine mission of the national curriculum in the field of physical education and sports in school is to provide appropriate mechanisms for designing, compiling, implementing and evaluating the physical education curriculum at all levels in order to comply with the philosophy of Islamic education, educational and training concepts. The field of physical education should be systematically structured for children and adolescents, depict a lively environment and a lovely school, and be able to provide the ultimate vision of physical education and sports for student which is the full synergy of "education, edification, and implementation". Previous researchers have focused primarily on school sport as a single entity, with far less consideration for the different policies available to guide sport management and delivery in the school context (1). Administrators of sport in schools in line with provincial and headquarters sections are planned

*. Corresponding Author:

Mohammad Rahim, Ph.D

E-mail: mohrah60@gmail.com 
to attain goals in a five-year vision as follows: Raising knowledgeable, capable, active, skilled, and cheerful students, realizing their academic responsibilities, participating in sports and physical education activities, having mobility, physical and mental fitness, and having a healthy and active lifestyle (2). Physical education and sports in schools are significantly important in developing future professional athletes from early ages and promoting common health in society (3). Although there are some scattered missions, policies and strategies in physical education and sport in school, they seem to be inconsistent (4). Nonetheless, most specified strategies are not followed, as well as not updated due to development of organization structure, fluctuation in economical, technological and social context, and also variations in the career environment. On the other hand, due to managerial changes and variations in educational policies and procedures in schools, it is necessary to reconsider the strategies of physical education and sports in schools, considering the obvious gap between strategies and operational measures (5). In recent years, Fundamental Reform Document of Education (FRDE) in Iranian schools' education (specially the biophysical aspects) is designed to focus on harmonic and continuous education of students, acquisition of basic competencies by students to assess risks, consideration of the potential consequences of risks and understanding their biological and physical status and practice to improve it. It is expected that with the progressive implementation of these guidelines, the students will be oriented in the face of serious life situations by assessing their awareness and self-control (6).

Moreover, national curriculum as a main subdivision of FRDE and a comprehensive learning plan is supposed to pro-vide the ground for a deep, extensive, and all-inclusive reform in educational contents. In the physical education and health section of FRDE it is stated that the purpose of this program is to establish complete physical and mental health of students as a divine gift and use the right methods of physical activity, improve physical and motor abilities, explain healthy recreational methods, promote health and healthy living principles, prevention of disease and disorders and empowerment of people in managing their behaviors and maintaining health. This transformative program, by providing various and comprehensive educational opportunities, seeks to enable students to acquire the necessary competencies to understand and correct the situations based on the Islamic standard system and to develop and continuously enhance their identity to achieve a higher level (7). The discussion highlights intriguing implications for sport administrators regarding school sport policy, particularly as it pertains to promoting school belongingness (1).

Considering the existence of FRDE as a national guideline, there is a need to design strategies for physical education and sports in schools, so that due to the limited resources, reaching the desired targets and plans outlined in the FRDE become possible. The crucial role of strategies in development of various factors has encouraged many administrators at sport organizations to pay time and money to designing apt strategies (8).

Strategic management is the art and science of design, perform, and evaluation of multiple task decisions which make the organization able to achieve long term goals (9). In this regard, Comprehensive framework of strategic planning is applied by organizations (10). This framework provides tools and methods that are appropriate for a variety of organizations in a variety of sizes and helps strategists identify, evaluate, and select strategies.

This comprehensive strategy formulation framework has four main stages, which are:

1- The starting stage in which the mission statement of the organization is prepared.

2- The input stage, which includes the preparation of matrices for evaluating internal and external factors.

3- Adaptation and comparison stage in which the main external and internal factors are adapted using tools such as SWOT matrix and internal and external factor matrix to identify strategies in line with the organization's mission.

4- The decision stage in which the different options of the strategies identified in the implementation stage are evaluated using the QSPM matrix and their relative attractiveness is determined (11).

In planning the strategy, care must be taken that the formulated strategies are feasible and so-called 
pragmatic, and the timing of the strategy and who is involved in its implementation must be clear.

The challenge of constructing a strategy is summarized in being new, up-to-date, reacting to changing conditions and being opportunistic (12). Therefore, in this study, the strategic planning of physical education and sports in Iranian schools was performed using the QSPM matrix.

\section{MATERIALS AND METHODS}

This research follows a mixed method (qualitative quantitative) and is classified as applied researches in terms of purpose. The main research tools include the following: Questionnaire, in the qualitative part, the participants included thirteen professors and knowledgeable experts in the field of education who were interviewed to determine the main components of the questionnaire. The statistical sample of the quantitative section was 120 experts in the field of physical education and sports at the staff and provincial levels.

Table 1. Distribution of participants based on major and

\begin{tabular}{lcc} 
& education level & \\
\hline Variable & Frequency & Percent \\
\hline Major & 116 & \\
$\begin{array}{l}\text { Physical } \\
\text { educa-tion }\end{array}$ & & 96.7 \\
$\quad \begin{array}{l}\text { Other majors } \\
\text { Education level }\end{array}$ & 4 & 3.3 \\
B.Sc. & 6 & 5 \\
M.Sc. & 63 & 52.5 \\
\hline PhD student & 14 & 11.6 \\
Ph.D. & 27 & 30.9 \\
\hline
\end{tabular}

The statistical population of this research includes experts, managers, heads of physical education and health departments of provincial education departments and headquarters. (32 general administrations and headquarters: from each department, the deputy director of physical education, the head of the physical education department and the physical education expert were among the audience, and a total of 96 people from the provinces and 24 from the headquarters). The number of samples was considered equal to the population. Questionnaires were distributed among all individuals.

\section{RESULTS}

Based on data shown in table 1, almost 97 percent of participants reported physical education as their major in university. Additionally, more than 50 percent of participants reported the Master of Science as their education level. 2- IFE, EFE and SWOT matrices to determine strategic position and strategy development and quantitative strategic planning matrix (QSPM) to prioritize strategies were used.

Examining the external factors evaluation matrix and the internal factors evaluation matrix, SWOT, strategic position analysis was shown. According to this study and matrix of strategic planning, quantitative physical education and sports in schools have 6 opportunities, 6 threats, 6 strengths and 6 weaknesses. The sum of the coefficients of the matrix of external factors is 2.73 and the sum of the coefficients of the matrix of internal factors is 2.77 . Thus, the strategic position of physical education and sports in schools was shown in the offensive position. Table 2 shows the evaluation of external factors and Table 4 shows the evaluation of internal factors of physical education and sports in schools:

The above figure indicates the strategic position of physical education and sports in Iranian schools. Matrix analysis showed that Iranian students` physical education and sports are in an offensive position. In reviewing the SWOT matrix and strategies, it was determined that Iranian students` physical education and sports have six strengths, six weaknesses, six opportunities and six threats, and finally four SO strategies, two WO strategies, two ST strategies, and one WT strategy establishing nine strategies in total.

Tables 4 and 5 show the QSPM matrix. According to the QSPM matrix analysis for Iranian schools' physical education and sports, there are six strengths, six weaknesses, six opportunities and six threats, and also four SO strategies, two WO strategies, two ST strategies and one WT strategy, besides there are a total of nine strategies which policymakers should pay more attention to them: (prioritization and rank of strategies is determined in Table 6).

1. "Development of students' motor literacy and promotion of dynamic lifestyle"

2. "School-centered physical education lessons activities"

3. "Strengthening program and extracurricular activities of school physical education lessons"

4. "Quality of space and student sports equipment in schools" 
Table 2. Matrix of evaluation of external factors of physical education and sports inn schools

\begin{tabular}{|c|c|c|c|c|}
\hline Number & Statement & $\begin{array}{l}\text { Coefficient of } \\
\text { significance }\end{array}$ & $\begin{array}{l}\text { Intensity of } \\
\text { factor }\end{array}$ & Score \\
\hline \multicolumn{5}{|c|}{ Opportunities } \\
\hline 01 & Existence of school as an official and extensive educational base in Iran & 0.1 & 4 & 0.4 \\
\hline 02 & Regular and mandatory attendance of infants and adolescents in schools & 0.08 & 3 & 0.24 \\
\hline 03 & People's trust in teachers and schools & 0.1 & 4 & 0.4 \\
\hline 04 & $\begin{array}{l}\text { Existence of attitude on the positive effect of exercise on children's health } \\
\text { in society }\end{array}$ & 0.08 & 3 & 0.24 \\
\hline 05 & $\begin{array}{l}\text { Emphasis of strategic documents (FRDE, national curriculum, etc.) on } \\
\text { physical activity }\end{array}$ & 0.09 & 4 & 0.36 \\
\hline 06 & $\begin{array}{l}\text { Improving the effective attitude and promoting the scientific view of } \\
\text { physical education and sports in recent years }\end{array}$ & 0.07 & 4 & 0.28 \\
\hline \multicolumn{5}{|c|}{ 皮 } \\
\hline $\mathrm{T} 1$ & Promoting machinery life, sedentary and inactive lifestyle & 0.09 & 2 & 0.18 \\
\hline $\mathrm{T} 2$ & $\begin{array}{l}\text { Lack of funds allocated to physical education and sports in school from } \\
\text { the total budget of sports in the country }\end{array}$ & 0.1 & 2 & 0.2 \\
\hline $\mathrm{T} 3$ & $\begin{array}{l}\text { Insignificant share of physical education and sports in the main programs } \\
\text { of other institutions in charge of sports in Iran }\end{array}$ & 0.07 & 2 & 0.14 \\
\hline $\mathrm{T} 4$ & $\begin{array}{l}\text { Lack of willingness of the non-governmental and private sector to invest } \\
\text { in student sports }\end{array}$ & 0.08 & 1 & 0.08 \\
\hline T5 & $\begin{array}{l}\text { Lack of financial ability and cultural poverty in placing the costs of sports } \\
\text { activities in the household basket }\end{array}$ & 0.07 & 1 & 0.07 \\
\hline T6 & $\begin{array}{l}\text { Lack of public media attention to the field of physical education and } \\
\text { sports in schools }\end{array}$ & 0.07 & 2 & 0.14 \\
\hline
\end{tabular}

Table 3. Matrix of evaluation of internal factors of physical education and sports in schools

\begin{tabular}{|c|c|c|c|c|}
\hline Number & Statement & $\begin{array}{c}\text { Coefficient of } \\
\text { significance }\end{array}$ & $\begin{array}{l}\text { Intensity of } \\
\text { factor }\end{array}$ & Score \\
\hline \multicolumn{5}{|l|}{ Strengths } \\
\hline S1 & $\begin{array}{l}\text { having a coherent structure governing physical education and sports in } \\
\text { school ranged from the ministry to the school }\end{array}$ & 0.09 & 4 & 0.36 \\
\hline $\mathrm{S} 2$ & $\begin{array}{l}\text { having educated and specialized human resources in physical education } \\
\text { and sports in schools }\end{array}$ & 0.1 & 4 & 0.4 \\
\hline S3 & $\begin{array}{l}\text { having a national curriculum and content of physical education course for } \\
\text { all levels }\end{array}$ & 0.09 & 4 & 0.36 \\
\hline S4 & $\begin{array}{l}\text { Existence of sports facilities belonging to education department in the } \\
\text { country }\end{array}$ & 0.07 & 3 & 0.21 \\
\hline S5 & $\begin{array}{l}\text { Existence of attractiveness in physical education and sports and students' } \\
\text { interest in physical activity }\end{array}$ & 0.09 & 3 & 0.27 \\
\hline S6 & $\begin{array}{l}\text { Existence of a budget line called physical education and health in the } \\
\text { education budget of Iran }\end{array}$ & 0.09 & 4 & 0.36 \\
\hline \multicolumn{5}{|c|}{ Weaknesses } \\
\hline W1 & $\begin{array}{l}\text { Inadequacy of the number of human resources specialists in physical } \\
\text { education courses with the student population }\end{array}$ & 0.09 & 2 & 0.18 \\
\hline W2 & $\begin{array}{l}\text { Incompatibility of available space and equipment of physical education } \\
\text { with national curriculum and subsystems }\end{array}$ & 0.1 & 2 & 0.2 \\
\hline W3 & $\begin{array}{l}\text { Functional weakness and inattention in teaching based on the content } \\
\text { compiled by some physical education teachers }\end{array}$ & 0.07 & 2 & 0.14 \\
\hline W4 & Lack of procedures and financial foundations in schools to generate income & 0.08 & 1 & 0.08 \\
\hline W5 & Structural, administrative and financial weakness of student sports boards & 0.07 & 1 & 0.07 \\
\hline W6 & Weakness of physical education and sports in girls' schools & 0.07 & 2 & 0.14 \\
\hline
\end{tabular}

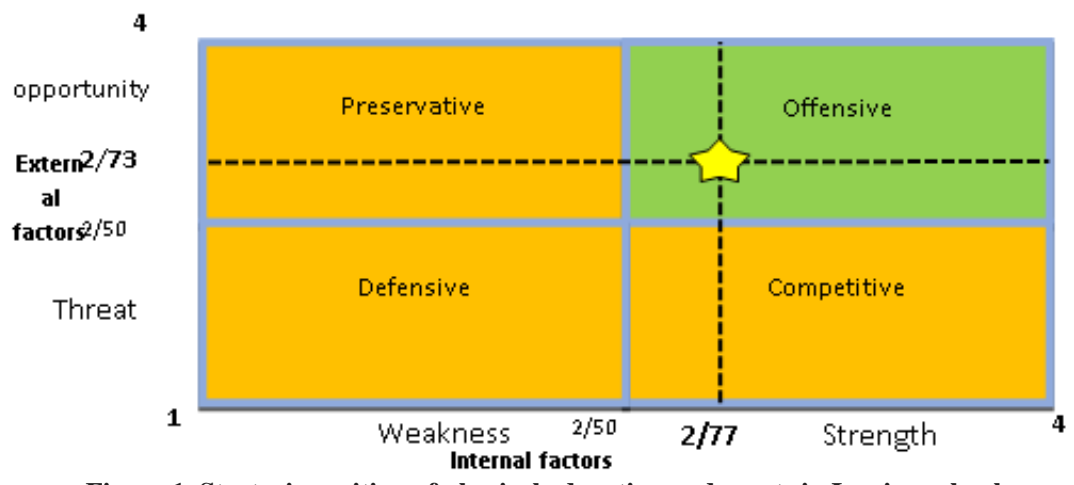

Figure 1. Strategic position of physical education and sports in Iranian schools 
Table 4. QSPM matrix for prioritization of external factors

\begin{tabular}{|c|c|c|c|c|c|c|c|c|c|c|c|c|c|c|c|c|c|c|c|}
\hline \multirow[b]{2}{*}{$\begin{array}{l}\text { Sum } \\
\text { score }\end{array}$} & \multirow[b]{2}{*}{$\begin{array}{l}\text { attractiveness } \\
\text { score }\end{array}$} & \multicolumn{2}{|c|}{$\begin{array}{c}\text { Develop students' } \\
\text { motor literacy and } \\
\text { promote a dynamic } \\
\text { lifestyle }\end{array}$} & \multicolumn{2}{|c|}{$\begin{array}{l}\text { Strengthen physical } \\
\text { education program } \\
\text { and extracurricular } \\
\text { activities }\end{array}$} & \multicolumn{2}{|c|}{$\begin{array}{l}\text { Quality of space } \\
\text { and equipment for } \\
\text { student sports in } \\
\text { schools }\end{array}$} & \multicolumn{2}{|c|}{$\begin{array}{l}\text { Establishment and } \\
\text { consolidation of } \\
\text { administrative and } \\
\text { organizational } \\
\text { foundations of } \\
\text { student sports } \\
\text { boards }\end{array}$} & \multicolumn{2}{|c|}{$\begin{array}{l}\text { Development and } \\
\text { research in student } \\
\text { sports }\end{array}$} & \multicolumn{2}{|c|}{$\begin{array}{c}\text { Creating a } \\
\text { volunteer } \\
\text { movement in } \\
\text { student sports }\end{array}$} & \multicolumn{2}{|c|}{$\begin{array}{c}\text { Designing a } \\
\text { performance } \\
\text { management } \\
\text { system for physical } \\
\text { education lessons in } \\
\text { schools }\end{array}$} & \multicolumn{2}{|c|}{$\begin{array}{l}\text { Development of } \\
\text { internal and } \\
\text { external } \\
\text { communication in } \\
\text { schools and } \\
\text { capacity building } \\
\text { for financial } \\
\text { foundations, } \\
\text { marketing and } \\
\text { income generation } \\
\text { with the } \\
\text { participation of } \\
\text { families and other } \\
\text { institutions }\end{array}$} & \multirow[b]{2}{*}{$\begin{array}{l}\text { External } \\
\text { factors }\end{array}$} & \multirow[b]{2}{*}{$\begin{array}{l}\text { Coefficient of } \\
\text { significance }\end{array}$} \\
\hline & & $\begin{array}{l}\text { Sum } \\
\text { score }\end{array}$ & $\begin{array}{l}\text { attractiveness } \\
\text { score }\end{array}$ & $\begin{array}{l}\text { Sum } \\
\text { score }\end{array}$ & $\begin{array}{l}\text { attractiveness } \\
\text { score }\end{array}$ & $\begin{array}{l}\text { Sum } \\
\text { score }\end{array}$ & $\begin{array}{l}\text { attractiveness } \\
\text { score }\end{array}$ & $\begin{array}{l}\text { Sum } \\
\text { score }\end{array}$ & $\begin{array}{l}\text { attractiveness } \\
\text { score }\end{array}$ & $\begin{array}{l}\text { Sum } \\
\text { score }\end{array}$ & $\begin{array}{l}\text { attractiveness } \\
\text { score }\end{array}$ & $\begin{array}{l}\text { Sum } \\
\text { score }\end{array}$ & $\begin{array}{l}\text { attractiveness } \\
\text { score e }\end{array}$ & $\begin{array}{l}\text { Sum } \\
\text { score }\end{array}$ & $\begin{array}{l}\text { attractiveness } \\
\text { score }\end{array}$ & $\begin{array}{l}\text { Sum } \\
\text { score }\end{array}$ & $\begin{array}{l}\text { attractiveness } \\
\text { score }\end{array}$ & & \\
\hline 0.4 & 4 & 4 & 0.4 & 4 & 0.4 & 4 & 0.4 & 4 & 0.4 & 4 & 0.4 & 1 & 0.1 & 4 & 0.4 & 4 & 0.4 & & \\
\hline 0.24 & 3 & 4 & 0.32 & 3 & 0.24 & 4 & 0.32 & 4 & 0.32 & 3 & 0.24 & 3 & 0.24 & 1 & 0.08 & 2 & 0.16 & & \\
\hline 0.4 & 4 & 4 & 0.4 & 4 & 0.4 & 4 & 0.4 & 4 & 0.4 & 2 & 0.2 & 1 & 0.1 & 2 & 0.2 & 3 & 0.3 & O3 & 0.1 \\
\hline 0.24 & 3 & 1 & 0.08 & 2 & 0.16 & 3 & 0.24 & 2 & 0.16 & 3 & 0.24 & 3 & 0.24 & 3 & 0.24 & 3 & 0.24 & $\mathrm{O} 4$ & 0.08 \\
\hline 0.18 & 2 & 3 & 0.27 & 3 & 0.27 & 3 & 0.27 & 2 & 0.18 & 4 & 0.36 & 2 & 0.18 & 3 & 0.27 & 2 & 0.18 & O5 & 0.09 \\
\hline 0.07 & 1 & 1 & 0.07 & 2 & 0.14 & 4 & 0.28 & 4 & 0.28 & 3 & 0.21 & 3 & 0.21 & 3 & 0.21 & 2 & 0.14 & O6 & 0.07 \\
\hline 0.09 & 1 & 1 & 0.09 & 4 & 0.36 & 4 & 0.36 & 4 & 0.36 & 3 & 0.27 & 4 & 0.36 & 4 & 0.36 & 2 & 0.18 & $\mathrm{~T} 1$ & 0.09 \\
\hline 0.4 & 4 & 3 & 0.3 & 3 & 0.3 & 2 & 0.2 & 2 & 0.2 & 4 & 0.4 & 3 & 0.3 & 2 & 0.2 & 3 & 0.3 & $\mathrm{~T} 2$ & 0.1 \\
\hline 0.28 & 4 & 1 & 0.07 & 3 & 0.21 & 2 & 0.14 & 3 & 0.21 & 3 & 0.21 & 3 & 0.21 & 1 & 0.07 & 3 & 0.21 & $\mathrm{~T} 3$ & 0.07 \\
\hline 0.32 & 4 & 2 & 0.16 & 3 & 0.24 & 2 & 0.16 & 3 & 0.24 & 3 & 0.24 & 4 & 0.32 & 4 & 0.32 & 4 & 0.32 & $\mathrm{~T} 4$ & 0.08 \\
\hline 0.14 & 2 & 1 & 0.07 & 4 & 0.28 & 4 & 0.28 & 3 & 0.21 & 2 & 0.14 & 2 & 0.14 & 1 & 0.07 & 1 & 0.07 & T5 & 0.07 \\
\hline 0.07 & 1 & 2 & 0.14 & 2 & 0.14 & 2 & 0.14 & 3 & 0.21 & 1 & 0.07 & 3 & 0.21 & 3 & 0.21 & 2 & 0.14 & T6 & 0.07 \\
\hline 2.83 & - & - & 2.37 & - & 3.14 & - & 3.19 & - & 3.17 & - & 2.98 & - & 2.61 & - & 2.63 & - & 2.64 & $\begin{array}{l}\text { Sum of } \\
\text { external } \\
\text { factors }\end{array}$ & $1=\sum$ \\
\hline
\end{tabular}


Table 5. QSPM matrix for prioritization of internal factors

\begin{tabular}{|c|c|c|c|c|c|c|c|c|c|c|c|c|c|c|c|c|c|c|c|}
\hline \multicolumn{2}{|c|}{$\begin{array}{l}\text { Development of } \\
\text { internal and } \\
\text { external } \\
\text { communication in } \\
\text { schools and } \\
\text { capacity building } \\
\text { for financial } \\
\text { foundations, } \\
\text { marketing and } \\
\text { income generation } \\
\text { with the } \\
\text { participation of } \\
\text { families and other } \\
\text { institutions }\end{array}$} & \multicolumn{2}{|c|}{$\begin{array}{c}\text { Designing a } \\
\text { performance } \\
\text { management } \\
\text { system for physical } \\
\text { education lessons in } \\
\text { schools }\end{array}$} & \multicolumn{2}{|c|}{$\begin{array}{c}\text { Creating a } \\
\text { volunteer } \\
\text { movement in } \\
\text { student sports }\end{array}$} & \multicolumn{2}{|c|}{$\begin{array}{l}\text { Development and } \\
\text { research in student } \\
\text { sports }\end{array}$} & \multicolumn{2}{|c|}{$\begin{array}{l}\text { Establishment and } \\
\text { consolidation of } \\
\text { administrative and } \\
\text { organizational } \\
\text { foundations of } \\
\text { student sports } \\
\text { boards }\end{array}$} & \multicolumn{3}{|c|}{$\begin{array}{l}\text { Quality of space and } \\
\text { equipment for student } \\
\text { sports in schools }\end{array}$} & \multicolumn{2}{|c|}{$\begin{array}{l}\text { trengthen physical } \\
\text { ication program and } \\
\text { extracurricular } \\
\text { activities }\end{array}$} & \multicolumn{2}{|c|}{$\begin{array}{l}\text { Develop students' } \\
\text { notor literacy and } \\
\text { romote a dynamic } \\
\text { lifestyle }\end{array}$} & $\begin{array}{l}\text { School- } \\
\text { centered } \\
\text { physical } \\
\text { education } \\
\text { activities }\end{array}$ & \multirow[t]{2}{*}{$\begin{array}{l}\text { Coefficient } \\
\text { of } \\
\text { significance }\end{array}$} & \multirow[t]{2}{*}{ Interna } \\
\hline $\begin{array}{l}\text { Sum } \\
\text { score }\end{array}$ & $\begin{array}{l}\text { attractiveness } \\
\text { score }\end{array}$ & $\begin{array}{l}\text { Sum } \\
\text { score }\end{array}$ & $\begin{array}{l}\text { attractiveness } \\
\text { score }\end{array}$ & $\begin{array}{l}\text { Sum } \\
\text { score }\end{array}$ & $\begin{array}{l}\text { attractiveness } \\
\text { score }\end{array}$ & $\begin{array}{l}\text { Sum } \\
\text { score }\end{array}$ & $\begin{array}{l}\text { attractiveness } \\
\text { score }\end{array}$ & $\begin{array}{l}\text { Sum } \\
\text { score }\end{array}$ & $\begin{array}{l}\text { attractiveness } \\
\text { score }\end{array}$ & $\begin{array}{l}\text { Sum } \\
\text { score }\end{array}$ & $\begin{array}{l}\text { attractiveness } \\
\text { score }\end{array}$ & $\begin{array}{l}\text { Sum } \\
\text { score }\end{array}$ & $\begin{array}{l}\text { attractiveness } \\
\text { score }\end{array}$ & $\begin{array}{l}\text { Sum } \\
\text { score }\end{array}$ & $\begin{array}{l}\text { attractiveness } \\
\text { score }\end{array}$ & $\begin{array}{l}\text { Sum } \\
\text { score }\end{array}$ & $\begin{array}{l}\text { attractiveness } \\
\text { score }\end{array}$ & & \\
\hline 0.36 & 4 & 0.36 & 4 & 0.18 & 2 & 0.09 & 1 & 0.18 & 2 & 0.18 & 2 & 0.36 & 4 & 0.27 & 3 & 0.36 & 4 & 09/0 & S1 \\
\hline 0.2 & 2 & 0.3 & 3 & 0.3 & 3 & 0.3 & 3 & 0.2 & 2 & 0.3 & 3 & 0.4 & 4 & 0.4 & 4 & 0.3 & 3 & $1 / 0$ & S2 \\
\hline 0.18 & 2 & 0.27 & 3 & 0.27 & 3 & 0.27 & 3 & 0.09 & 1 & 0.36 & 4 & 0.36 & 4 & 0.36 & 4 & 0.36 & 4 & $09 / 0$ & S3 \\
\hline 0.21 & 3 & 0.14 & 2 & 0.14 & 2 & 0.07 & 1 & 0.28 & 4 & 0.28 & 4 & 0.21 & 3 & 0.21 & 3 & 0.21 & 3 & $07 / 0$ & S4 \\
\hline 0.09 & 1 & 0.36 & 4 & 0.18 & 2 & 0.18 & 2 & 0.18 & 2 & 0.27 & 3 & 0.27 & 3 & 0.27 & 3 & 0.18 & 2 & 09/0 & S6 \\
\hline 0.18 & 2 & 0.27 & 3 & 0.27 & 3 & 0.27 & 3 & 0.27 & 3 & 0.18 & 2 & 0.18 & 2 & 0.27 & 3 & 0.36 & 4 & $09 / 0$ & W1 \\
\hline 0.27 & 3 & 0.27 & 3 & 0.27 & 3 & 0.18 & 2 & 0.18 & 2 & 0.18 & 2 & 0.18 & 2 & 0.18 & 2 & 0.27 & 3 & 09/0 & W2 \\
\hline 0.12 & 2 & 0.24 & 4 & 0.18 & 3 & 0.18 & 3 & 0.12 & 2 & 0.06 & 1 & 0.18 & 3 & 0.24 & 4 & 0.18 & 3 & $06 / 0$ & W3 \\
\hline 0.32 & 4 & 0.08 & 1 & 0.24 & 3 & 0.16 & 2 & 0.24 & 3 & 0.24 & 3 & 0.08 & 1 & 0.24 & 3 & 0.24 & 3 & $08 / 0$ & W4 \\
\hline 0.24 & 3 & 0.24 & 3 & 0.32 & 4 & 0.08 & 1 & 0.32 & 4 & 0.08 & 1 & 0.16 & 2 & 0.32 & 1 & 0.32 & 4 & $08 / 0$ & W5 \\
\hline 0.21 & 3 & 0.28 & 4 & 0.14 & 2 & 0.21 & 3 & .21 & 3 & 0.28 & 4 & 0.28 & 4 & 0.28 & 4 & 0.14 & 2 & $07 / 0$ & W6 \\
\hline 2.74 & - & 2.9 & - & 2.85 & - & 2.17 & - & 2.63 & - & 2.77 & - & 3.02 & - & 3.16 & - & 3.19 & - & $1=\sum$ & $\begin{array}{l}\text { Sum of } \\
\text { internal } \\
\text { factors }\end{array}$ \\
\hline
\end{tabular}


Table 6. The scores and prioritization of strategies

\begin{tabular}{|c|c|c|}
\hline Statement & $\begin{array}{l}\text { Sum of } \\
\text { scores }\end{array}$ & Priority \\
\hline Develop students' motor literacy and promote a dynamic lifestyle & 35.6 & 1 \\
\hline School-centered physical education activities & 33.6 & 2 \\
\hline Strengthen the physical and extracurricular activities of schools & 19.6 & 3 \\
\hline Quality of space and equipment for student sports in schools & 75.5 & 4 \\
\hline $\begin{array}{l}\text { Development of internal and external communication in schools and capacity for financial } \\
\text { foundations and marketing }\end{array}$ & 57.5 & 5 \\
\hline Creating a volunteer movement in student sports & 49.5 & 6 \\
\hline Designing a performance management system for physical education lessons in schools & 27.5 & 7 \\
\hline $\begin{array}{l}\text { Establishment and consolidation of administrative and organizational foundations of student sports } \\
\text { boards }\end{array}$ & 24.5 & 8 \\
\hline Development and research in student sports & 8.4 & 9 \\
\hline
\end{tabular}

5. "Development of internal and external communication in schools and capacity building for financial foundations, marketing and income generation with the participation of families and other institutions"

6. "Creating a volunteer movement in student sports"

7. "Designing a physical education performance management system in schools"

8. "Establishment and consolidation of administrative and organizational foundations of student sports boards" a

9. "Development and research in the field of student sports"

Based on Table 6 , the order of priority of these goals in the program was determined and shown.

Accordingly, "Development of students' motor literacy and promotion of dynamic lifestyle", "School-centered physical education lessons activities" and "Strengthening program and extracurricular activities of school physical education les-sons" should be the main goals in physical education and sports in schools should be considered.

\section{DISCUSSION}

Physical education and training of students may have a positive impact on preventing physical inactivity and poor diet phenomena. Motor and dietary education can be a cornerstone to promote healthy life-styles (13). Participation in school sports was associated with higher grades, a better understanding of school safety, increased family understanding, and teacher / community support. Guidance is needed for parents, educators, and policymakers on how to further enhance students' academic and social success (14). The development of students' motor literacy and the promotion of a dynamic lifestyle was the first goal in the middle, emphasizing the child's basic need for dynamism and mobility in order to develop basic motor and sports skills and reduce obesity to enable students in childhood (12).

Students should be encouraged to move with motivation, confidence and control in a range of physical and rhythmic activities and sports and respond appropriately to existing environmental conditions (15). Developing students' motor literacy and promoting a dynamic lifestyle will pave the way for general education and social development of students and seeks to provide conditions for the development of motor literacy and a healthy and dynamic lifestyle in them, in line with what is planned in the program. A longterm development has been proposed in Canada, in which the development of basic motor skills and basic sports skills in student's leads to the development of motor literacy, and the development of motor literacy leads to an active lifestyle (16).

This model is aligned with the goal of developing students' motor literacy and promoting a dynamic lifestyle. The aim of this study was to develop a strategic plan for physical education and sports in Iranian schools using QSPM. Our analysis showed six strengths, six weaknesses, six opportunities and six threats, as well as four SO strategies, two WO strategies, two ST strategies and one WT strategy and a total of nine strategies for physical education and sports in Iranian schools.

Strengthening the program and extracurricular activities of school physical education courses in line with the development of motor literacy can be two wings of physical education and sports in schools, in order to improve the quality of physical education lessons. Castelli et al. (2014) 
(17) suggested that the ages of six to nine for boys and six to eight for girls are important in learning and developing of motor literacy and fundamental skills (agility, balance, coordination, and speed), and it is recommended that at this ages, fundamental motor skills be preceded by specific skills. Exercise should be practiced, and in the meantime, the task of developing these skills through unstructured games in a safe environment is the responsibility of physical education teachers.

The holistic program of physical education includes: activities of physical education course and also administration of intra-school sport games, determining intra-school and out-ofschool sports centers, allocating an activity place for physical training with family, dynamic school, student sports association, etc. Development of extracurricular activities for physical education and sports for students, increases motor literacy, improves productivity, and further improves performance in the field of physical education and sports.

The goal of developing internal and external communication in schools and capacity building for financial, marketing and income-generating foundations with the participation of families and other institutions in order to advance the strategic goals of physical education is explained regarding the participation of other institutions in public education. Of course, today's demands of school principals in attracting external funds and financial contributions reflect the need of schools to attract resources in various fields, especially in physical education and sport events, as well as quantitative and qualitative improvement of sports facilities, equipment and tools needed in schools. Although, the FRDE has some guidelines in the biological and physical fields of interaction and participation of all institutions, effective factors in the field of physical education and health should be determined in future researches.

Creating a volunteer movement in student sports can also lead to social growth, optimal use of existing potential work-force and improvement of the country's future human resources in the real work environment. The establishment and consolidation of administrative and organizational foundations of student sports is an effective strategy which is achieved by strengthening the organizational and administrative foundations of the Students Sports Federation and related organizations working in student sports.

Quality of space and equipment for student sports in schools as a strategic goal of physical education and sport play an effective role in the development of physical education classes and extracurricular programs of physical education, be-cause quality of physical education and sport events inside and outside of schools depend on the quality of space and equipment.

Designing a physical education performance management system in schools will certainly complement the optimal implementation of physical education in schools, given the development of a national curriculum and teacher's textbooks, because this assessment will lead to the optimal implementation of goals and the creation of a motivating force for improvement. This is in line with the findings of Abbasi et. al (2016) which stated that when teens' and children's internal motivation for participation is supported by families, elite sport talents will have opportunity for develop (18).

Performance and productivity in physical education, monitoring of working conditions and changing motivating methods of teaching physical education, reviewing rules, regulations, guidelines and improving trends and technology in the field of physical education will lead to the development of physical literacy. Dynamic lifestyle will ensure the success of the physical education course in training and preparing today's generation for tomorrow's life. It is worth mentioning that this goal is in line with the 13th goal of FRDE; the establishment of an evaluation and quality assurance system in formal and public education.

The purpose of development and research in the field of student sports is in accordance with strategies outlined in the FRDE, which aims to increase research and development in the field of "service and promotion of social health". Research and innovation, theorizing and documenting educational experiences, and the optimal use of existing capacities to expand research are recommended as suitable strategies. Productivity includes efficiency and effectiveness, which includes using production resources without wasting them and measuring the achievement of predetermined goals. In efficiency, profitability is important, and in effectiveness, achieving the goal. 
It seems that school-centered activities by planning students' motor literacy development and promoting a dynamic lifestyle and strengthening the program and extracurricular activities of school physical education lessons will develop productivity in school physical education and sports. It will be acknowledged that no particular cause or factor can be considered as the ultimate reason for increasing the productivity of physical education in schools; but since product development is a combination of influential factors, each factor can be considered effective in turn. However, to have a dynamic society, we need to increase motor literacy, physical and mental literacy, especially with focus on fundamental motor skills. With this logic, educating a generation with sufficient motor literacy can guarantee a quality of life in the future to an acceptable degree.

\section{CONCLUSION}

Overall, the strategic plans for physical education and sports in Iranian schools which are important to notice are as follows: "developing students' motor literacy and promoting a dynamic lifestyle", "school-centered physical education activities", "strengthening school activities and extracurricular activities", "quality of student sports space and equipment in schools", "development of internal and external communication in schools and capacity building for financial foundations, marketing and income generation with the participation of families and other institutions", "Creating a volunteer movement in student sports", "Designing a Physical Education Management Performance Management System in Schools", "Establishing and Consolidating Administrative Foundations, Organizing Student Sports Boards" and "Development and Research in Student Sports".

\section{APPLICABLE REMARKS}

- It also seems that based on the prioritization of strategies, the development of students' motor literacy and the promotion of a dynamic lifestyle should be considered as the main target of policymakers in physical education and sports in schools.

\section{REFERENCES}

1. Jones GJ, Hyun M, Edwards MB, Casper J, Bocarro JN, Lynch J. Is "school sport" associated with school belongingness? Testing the influence of school sport policy. Sport Manag Rev. 2020;23(5):925936. doi: 10.1016/j.smr.2019.12.003

2. Gholami K, Salehi Omran E, Izadi S, Saffar Heidari H. Developing a Standard Model of Teachers' Professional Competence on the Basis of High Level Documents in Iran. Iran J Edu Soc. 2019;2(2):4459. doi: 10.29252/ijes.2.2.44

3. Hills AP, Dengel DR, Lubans DR. Supporting public health priorities: recommendations for physical education and physical activity promotion in schools. Prog Cardiovasc Dis. 2015;57(4):368-374. doi: 10.1016/j.pcad.2014.09.010 pmid: 25269062

4. Kohl III HW, Cook HD. Educating the student body: Taking physical activity and physical education to school: National Academies Press; 2013.

5. Dagkas S, Stathi A. Exploring social and environmental factors affecting adolescents' participation in physical activity. Europ Physic Edu Rev. 2016;13(3):369-384. doi: 10.1177/1356336x07081800

6. Parker AE, Kupersmidt JB, Mathis ET, Scull TM, Sims C. The impact of mindfulness education on elementary school students: Evaluation of the Master Mind Program. Adv Sch Ment Health Promot. 2014;7(3):184-204. doi: 10.1080/1754730X.2014.916497 pmid: 27057208

7. Nemati T, Panahi AG. Problems of Fundamental Reform Document of Education (FRDE) in the Education System in Iran (A Meta-Analysis). J Financ Analysis. 2019;2(1):45-56.

8. McLaughlin MW. Community counts: How youth organizations matter for youth development. Washington, DC.: Public Education Network, 2000.

9. Barnabè F. A "system dynamics-based Balanced Scorecard" to support strategic decision making. Int J Product Perform Manag. 2011;60(5):446-473. doi: 10.1108/17410401111140383

10. Bryson JM. Strategic planning for public and non-profit organizations: A guide to strengthening and sustaining organizational achievement: John Wiley \& Sons; 2018.

11. Nejatian M, Zarei MH. Moving Towards Organizational Agility: Are We Improving in the Right Direction? Glob J Flexible Sys Manag. 2013;14(4):241-253. doi: 10.1007/s40171-013-0048-3 
12. Blythe SG. The importance of movement in early development-the foundation of developing physical literacy. Presidents Message. 2013;12(1):15.

13. Varriale L, Briganti P, Guillot G, Ascione A. Motor and dietary education against obesity for students: Evidence from Italy. J Human Sport Exercise. 2019;14(3). doi: 10.14198/jhse.2019.143.19

14. Van Boekel M, Bulut O, Stanke L, Palma Zamora JR, Jang Y, Kang Y, et al. Effects of participation in school sports on academic and social functioning. J Appl Dev Psychol. 2016;46:31-40. doi: 10.1016/j.appdev.2016.05.002

15. Robinson DB, Randall L, Barrett J. Physical Literacy (Mis)understandings: What do Leading Physical Education Teachers Know About Physical Literacy? J Teach Physic Edu. 2018;37(3):288-298. doi: 10.1123/jtpe.2018-0135

16. Balyi I, Way R, Higgs C. Long-Term Athlete Development: Human Kinetics Library; 2013.

17. Castelli DM, Centeio EE, Beighle AE, Carson RL, Nicksic HM. Physical literacy and Comprehensive School Physical Activity Programs. Prev Med. 2014;66:95-100. doi: 10.1016/j.ypmed.2014.06.007 pmid: 24937650

18. Abbasi H, Khanmoradi S, Eydi H, Rasekh N. Quantitative strategic planning of General Office of Sports and Youth in regard to championship sport using QSPM in Kermanshah. Int J Sport Sci. 2016;6(2):3645. 